\title{
KSZTAŁTOWANIE KOMPETENCJ KOMUNIKACYJNYCH NA POZIOMIE AKADEMICKIM. ARS BENE DICENDI \\ NA PRZYKLADZIE MOWY OSKARŻYCIELSKIEJ HIPOLITA KIRYLOWICZA Z POWIEŚCI „BRACIA KARAMAZOW” FIODORA DOSTOJEWSKIEGO
}

\author{
MARCIN KRAWCZAK \\ ARTUR URBANIAK
}

\begin{abstract}
The paper proposes the employment of exemplary rhetorical tropes and figures present in literary works for further development of presentation skills in tertiary education students through strengthening their communicative competence. It reflects on rhetorical devices (both semantic and syntactic) and figurative language based on Dostoevsky's Karamazov Brothers to be later-on used in a contemporary business context to a make any public presentation less of a bore. It strongly promotes and hopefully envisions the great comeback of long-forgotten rhetorical studies that should be reintroduced in HEI agendas in the form of Interpersonal Communication and Public Presentation courses.
\end{abstract}

Key words: rhetoric, communicative competence, public speaking 


\section{Uwagi wstępne}

Kanwą dla niniejszego studium stała się lektura mowy oskarżycielskiej prokuratora Hipolita Kiryłowicza z powieści Fiodora Dostojewskiego, „Bracia Karamazow”, która obfituje w figury retoryczne. Mowa oskarżycielska jest bowiem przykładem specyficznego rodzaju wystąpienia publicznego, które ma za zadanie wzbudzić w odbiorcach określone emocje by osiągnąc zamierzone efekty. Analizując tekst wystąpienia pod kątem przydatności dla celów dydaktycznych w obszarze rozwijania lingwistycznych kompetencji komunikacyjnych należy zwrócić uwagę na kilka elementów, które wybrzmiały w powieści Dostojewskiego.

Hipolit Kiryłowicz przygotował był już dawno swoje przemówienie, mimo to, rozpoczynając je, był niesłychanie wzruszony. Kroplisty pot wystąpił mu na czoło, a zimne dreszcze wstrząsały nim nieustannie. Ale bo też uważał on to wystąpienie swoje jako arcydzieło nad arcydzieła, jako swój łabędzi śpiew, jakim się też stało rzeczywiście, bo w kilka miesięcy potem umarł na galopujące suchoty. Mowa też jego wywarła głębokie wrażenie, nawet na przeciwnikach. Trzeba tu zaznaczyć, że, wypowiadając ją, prokurator nie spełniał tylko oficyalnego obowiązku, ale wierzył najmocniej sam w słuszność swojej sprawy (F. Dostojewski, „Bracia Karamazow”, rozdział 10, dalej zwany TŹ).

Dostojewski w cytowanym fragmencie dzieła zwraca uwagę na to, co również zdaniem badaczy procesów komunikowania stanowi o wartości każdego publicznego wystąpienia. Po pierwsze sumienne przygotowanie ${ }^{1}$. Po wtóre warsztat komunikatora, czyli odpowiednio rozwinięte kompetencje komunikacyjne (tu: retoryczne), które Morreale, Spitzberg i Barge (2007: 65) zwięźle definiują jako kompetencję komunikacyjna określającą „,czy dana osoba komunikuje się skutecznie i stosownie do kontekstu”. Z kolei Kohout (2002: 99) zauważa, że „mistrz mowy, aby osiągnąć optymalny efekt, powinien korzystać nie tylko ze wszystkich swoich talentów i zdolności, ale także używać wszelkich dostępnych narzędzi”. Po trzecie wiara we własne słowa, która pełni niepoślednią funkcję w budowaniu wiarygodności. Allhoff i Alhoff (2008: 52) odnotowują, że „obok całej strategii retorycznej o tym, czy mówienie lub rozmowa zakończą się powodzeniem lub porażką, rozstrzygnie wyraźne zaangażowanie mówiącego" (por. Argyle i Henderson, 2005 tamże). Przyświeca nam zatem założenie, że dobrego mówcę należy kompleksowo wykształcić.

Dobry mówca - komunikator (za: Puppel, 2004; 2007) to osoba charyzmatyczna, zdolna przykuć i utrzymać uwagę odbiorców w czasie wystąpienia przed pu-

\footnotetext{
${ }^{1} \mathrm{O}$ tym jak istotne jest właściwe przygotowanie się do wystąpienia publicznego świadczyć może rosnąca liczba publikacji w tym zakresie. Wymienić można choćby cytowane w niniejszym artykule pozycje: R. Wiszniewski, Sztuka mówienia, Videograf, Katowice, 2003; D.W. Allhoff i W. Allhoff, Sztuka przekonywania do wtasnych racji, Wydawnictwo WAM, Kraków, 2008; C. Gallo, Talk like TED, St. Martin's Griffin, New York, 2014.
} 
blicznością. Jednak warto na wstępie wrócić do etymologii pojęcia charyzmatyczny. Greckie $\chi \dot{\alpha} \rho \imath \sigma \mu \alpha$ [kharízomai] oznacza bowiem łaskę, „dar od bogów, [...] dar darmo dany" (Budzyńska-Daca, 2008: 151). Skoro jednak nie każdy mówca posiada ten boski dar czy charyzmat, przyjmujemy, że należy wspierać kształcenie kompetencji miękkich, ze szczególnym uwzględnieniem rozwijania kompetencji komunikacyjnych u studentów uczelni wyższych, otwierając tym samym drzwi akademii przed komunikologami, czyli specjalistami w dziedzinie nauk o komunikowaniu międzyludzkim² ${ }^{2}$.

\section{Transkomunikator, czyli retor $\mathbf{2 . 0}$}

W retoryce klasycznej ars bene dicendi, czyli sztuka posługiwania się mową a nie językiem - jak zauważa Zgółka (2017: 41), w reprezentowanym tu ujęciu ekolingwistycznym stała się przedmiotem refleksji pod kątem rozwijania u studentów kompetencji komunikacyjnych w obszarze elementów lingwistycznych (językowych) komunikowania. Pojęcie transkomunikatora bierze początek w rozważaniach nad koncepcją strategicznego zarządzania kompetencją komunikacyjną zawartą w opisie modelu komunikacyjnego DRAAM (ang. domain-resource-agent-accessmanagement model of human communication, w: Puppel, 2004). W przytaczanym modelu kompetencje komunikacyjne definiuje się jako zdolność do administrowania zasobami językowymi i pozajęzykowymi w określonym kontekście sytuacyjnym. Kompetencje komunikacyjne obejmują cztery zasadnicze elementy: (1) środowisko zewnętrzne, ze ścisłym uwzględnieniem kontekstu sytuacyjnego, czyli szerzej uwarunkowania biologiczno-społeczno-kulturowe; (2) środowisko wewnętrzne z uwzględnieniem cech idiosynkratycznych komunikatora, czyli zdolność konkretnej osoby do posługiwania się mową oraz całym garniturem zachowań niewerbalnych; (3) dynamikę zachowań komunikacyjnych z uwzględnieniem relacyjnych uwarunkowań komunikowania się względem interlokutorów, bilansując zyski i straty; oraz (4) rezultaty, czyli skuteczność danego aktu komunikacyjnego (zob. Krawczak, 2017: 150-151). Transkomunikator jest zatem retorem odpowiadającym potrzebom XXI. wieku; multimodalnym, hybrydowym, elastycznym, zdolnym do skutecznych oddziaływań zarówno w komunikacji bezpośredniej twarzą w twarz - a także w komunikowaniu masowym (pośrednim; termin za: Dobek-Ostrowska, 2006: 74).

\footnotetext{
${ }^{2}$ To, że zdecydowaliśmy się tu na użycie terminu „komunikolog” najpełniej odzwierciedla stanowisko wyrażone przez E. Kulczyckiego (2012: 7), który zauważa, że komunikologia „wyraża coraz powszechniejszą ambicję ukształtowania refleksji nad komunikacją w ramach inter- i transdyscyplinarnej, ale jednak przede wszystkim samodzielnej dyscypliny naukowej. Wcześniej o rosnącej sile oddziaływania nowego paradygmatu w naukach o komunikowaniu pisał S. Puppel w artykule „Communicology: remarks on the reemergence of a paradigm in communication studies" (zob. Puppel 2008).
} 


\section{Kompetencje komunikacyjne ${ }^{3}$ a rynek pracy}

Rynek pracy dawno już dostrzegł potrzebę rozwijania tzw. umiejętności miękkich, do których tradycyjnie zaliczamy kompetencje komunikacyjne, włączając szeroko choć nieprecyzyjnie ujęte umiejętności komunikacyjne (ang. communication skills za: de Guzman i Choi, 2013). Te ostatnie wchodzą w zakres szerszego pojęcia - employability skills, czyli umiejętności podnoszących szanse na znalezienie, utrzymanie i poradzenie sobie w pracy (za: Robinson, 2000; Wobalis, 2016; Urbaniak, 2018). W myśl teorii kapitału ludzkiego (Becker, 1964) głównym zadaniem szkolnictwa wyższego jest wyposażenie absolwentów w zestaw umiejętności, dzięki którym odnajdą się oni w zmiennych realiach współczesnego rynku pracy. Kwestia konsekwentnego podnoszenia zdolności do zatrudnienia odzwierciedla się także w dokumentach regulujących zakres oraz ogólne ramy funkcjonowania systemów szkolnictwa europejskiego. Wobalis (2016) zwraca uwagę na obszerny dokument zatytułowany „Analiza kwalifikacji i kompetencji kluczowych dla zwiększenia szans absolwentów na rynku pracy"4, wydany przez Narodowe Centrum Badań i Rozwoju w 2014 roku, w którym przedstawiono kompleksowy obraz umiejętności, kwalifikacji i kompetencji absolwentów uczelni wyższych, uznanych za przydatne z punktu widzenia pracodawców.

Celem zapewnienia płynnego przechodzenia absolwentów szkół wyższych na rynek pracy od przynajmniej dwóch dekad prowadzi się badania nad wspomnianymi powyżej employablility skills, czyli umiejętnościami pozwalającymi zwiększyć szanse na zatrudnienie (zob. Maes, Weldy i Icenogle, 1997; Norwood i Henneberry 2006; Teichler, 2009; Velasco, 2012). Nie dziwi zatem fakt, jak odnotowują Ngang, Chan i Vetriveilmany (2015: 128-9), że rząd Malezji nałożył na tamtejsze Ministerstwo Edukacji obowiązek wzbogacenia programów kształcenia o umiejętności miękkie, wychodząc w ten sposób naprzeciw oczekiwaniom rynku pracy.

Rosnące zapotrzebowanie na pracowników posiadających odpowiednio ukształtowane kompetencje komunikacyjne sprawia, że w coraz bardziej stechnokratyzowanym świecie humaniści wcale nie są niepotrzebni (Bhattacharyya, 2018). Z kolei Kudrycka (2014) zauważa, że

gdy wiedza często jest redukowana do setek tysięcy informacji, szczęście staje się przedmiotem badań ekonomistów, a porywy serca są zapisywane jako wyrażenia matematyczne - filozofowie, literaturoznawcy, historycy, kulturoznawcy są potrzebni, aby selekcjonować, oceniać i uzasadniać te osiągnięcia, które mają trwałe znaczenie dla ludzkości ${ }^{5}$.

\footnotetext{
${ }^{3}$ Zagadnienie kompetencji komunikacyjnych i zakresu definicji tegoż pojęcia szczegółowo omawiają V. Bagarić i J.S. „Djigunović, Defining communicative competence”, (2007) oraz I. Kurcz, „Communicative competence and Theory of Mind”, (2004).

${ }^{4}$ „Analiza kwalifikacji i kompetencji kluczowych dla zwiększenia szans absolwentów na rynku pracy. Raport końcowy", Agrotec na zlecenie NCBiR, Warszawa 2014.

${ }^{5}$ B. Kudrycka, 2014, „Humaniści muszą wyjść ze skansenu”, źródło: IS 1 [dostęp: 20.09.2019].
} 
Wykształcenie odpowiednich kompetencji komunikacyjnych to swoisty elementarz współczesnego absolwenta uczelni wyższej. Przekładają się one bowiem bezpośrednio na praktyczną umiejętność komunikowania się w warunkach korporacji. McNatt (2019: 278) odnotowuje:

Od pewnego czasu organizacje podkreślają, że komunikacja słowna oraz umiejętności prezentacyjne znajdują się pośród kwalifikacji najbardziej pożądanych przez pracodawców oraz stanowią kluczowe kompetencje brane pod uwagę przy zatrudnieniu (Maes, Weldy i Icenogle, 1997). To nie budzi zdziwienia zważywszy, że badania pokazują, iż pracownicy, którzy posiadają lepiej rozwinięte umiejętności komunikowania się i prezentowania publicznego są wyżej oceniani i osiągają większe sukcesy [...]. (Tłumaczenie $\mathrm{AU})$.

Przy czym należy mieć na uwadze, że mowa tu o kompetencjach komunikacyjnych definiowanych nie tylko jako zdolność do zwięzłego przekazywania komunikatu (w myśl paradygmatu transmisji, zob. Kulczycki, 2012: 27-35), lecz nade wszystko jako zdolność szukania wspólnej płaszczyzny porozumienia, dzielenia się wiedzą. Zgodnie z definicją komunikacji, wywodzącą się od łacińskiego communio oznaczającego wspólnotę i communicare oznaczającego „łączyć”, „,czynić wspólnym" (za: Dobek-Ostrowska, 2006: 61; por. Urbaniak, 2014: 20; Gondek, 2015: 20).

$\mathrm{Na}$ znaczeniu zyskują nade wszystko sztuka prowadzenia wystąpień publicznych oraz umiejętności komunikowania grupowego, włączając zdolność (auto)prezentacji, gotowość do prowadzenia zebrań z podwładnymi, umiejętność zwięzłego referowania postępów w pracy nad projektem, biegłość w poprowadzeniu codziennego scrum 'u lub standup'u. Innym obszarem komunikowania, który zdecydowanie wymaga kształcenia jest rozwijanie umiejętności pracowników niższego szczebla kierowniczego do udzielania feedbacku, czyli okresowej oceny postępów pracownika, które przybiera zwykle formę interakcji bezpośredniej (1:1). Wyżej wymienione to jedne $\mathrm{z}$ najbardziej pożądanych umiejętności miękkich, na które wskazują pracodawcy. Umiejętności, doprecyzujmy, wśród których wymienia się w dziesiątce najbardziej pożądanych kwalifikacji: komunikację (na drugim miejscu), pracę w grupie (na trzecim), negocjacje i perswazję (na czwartym) ${ }^{6}$. Znajduje to potwierdzenie w innym rankingu, a mianowicie zestawieniu dwunastu najbardziej pożądanych umiejętności miękkich, gdzie Loretto (2019) wymienia przywództwo i perswa zję (na drugim miejscu), doskonałe umiejętności komunikacyjne i interpersonalne (na szóstym) a pracę w grupie (na jedenastym) ${ }^{7}$. W konsekwencji, zadaniem uczelni wyższych, włączając uczelnie medyczne (Wiertlewska, 2017), jak i techniczne (Urbaniak, 2018), jest ustawiczne dążenie do rozwoju kompetencji komunikacyjnych przyszłych pracowników.

${ }^{6}$ „What are the top 10 skills that'll get you a job when you graduate?”, źródło: IS 2 [dostęp: 20.09.2019].

${ }^{7}$ P. Loretto, 2019. „The Top 12 Soft Skills Employers Seek”, źródło: IS 3 [dostęp: 20.09.2019]. 
W obszarze lingwistycznych - perswazyjnych środków oddziaływania wyróżniamy tropy, figury retoryczne, figury słowne, a także figury myśli (podział za: Korolko, 1990), które znaleźć mogą zastosowanie w kompleksowym przygotowaniu przyszłych mówców - transkomunikatorów do wywierania zamierzonych efektów komunikacyjnych. Przykłady zaczerpnięte z literackiego tekstu, mowy oskarżycielskiej Hipolita Kiryłowicza, stanowią bazę, z której mogą czerpać przyszli adepci ars bene dicendi.

\section{Analiza środków retorycznych mowy oskarżycielskiej Kiryłowa ${ }^{8}$}

W zakresie rozbudowywania u studentów lingwistycznych kompetencji komunikacyjnych, pozwalających na skuteczne zjednywanie sobie odbiorców podczas prezentacji publicznych, sugeruje się sięgnięcie do przykładów literackich. Właściwa analiza tekstu literackiego pozwoli zapoznać słuchaczy z licznymi tropami i figurami retorycznymi, które pozwolą podnieść umiejętność przemawiania publicznego na wyższy poziom.

Kontekst sytuacyjny potrzebny jest do określenia sytuacji retorycznej. W omawianym przykładzie literackim prokurator Hipolit Kiryłowicz oskarża Dymitra Karamazowa, syna Fiodora Pawłowicza Karamazowa, uchodzącego w lokalnej społeczności za cynicznego rozpustnika, o ojcobójstwo, do którego doszło wskutek chorobliwej rywalizacji między ojcem a synem o względy Gruszeńki Swietłowej, pięknej kobiety nie najlepszej proweniencji.

Linia argumentacyjna prokuratora opiera się na założeniu, że popełnione ojcobójstwo jest niepokojącym przejawem postępującej degrengolady społeczeństwa. Uwiarygodniając swoje oskarżenie prokurator odmalowuje przed audytorium „,potworności rozkiełznanej woli i moralnego upadku", przytaczając przykłady podobnych zdarzeń, które niedawno miały miejsce w Carskiej Rosji (oficer wojskowy zabijający swego dobroczyńcę). W przemowie Kiryłowicza dominuje funkcja informująco-pouczająca, ponieważ prokurator w sposób bezpośredni próbuje przekonać zgromadzonych o winie oskarżonego Dymitra Karamazowa, opierając się na przesłankach racjonalistycznych oraz zgromadzonych dowodach. Dodatkowo, jak podaje Michałowski (2015: 3), postać Kiryłowa uosabia to co u Dostojewskiego jest szczególnie eksponowane: ambiwalencję natury ludzkiej; w swojej przemowie Kiryłow nierzadko wraca do tego pojęcia w wymiarze retorycznym. Czyn oskarżonego, będący oznaką dehumanizacji, musi zostać dokumentnie i przykładnie potępiony jako wyraz społecznej dezaprobaty wobec takich zachowań oraz odzwierciedlenie

\footnotetext{
${ }^{8}$ Wszystkie odniesienia oznaczone w niniejszej sekcji jako TŹ (tekst źródłowy) pochodzą z powieści „Bracia Karamazow” Fiodora Dostojewskiego, w szczególności zaś z rozdziału 10, zatytułowanego „Omyłka sądu”.
} 
sprawnie działającego wymiaru sprawiedliwości. Sprawa Karamazowa zyskała rozgłos ogólnopaństwowy a prokurator przypominający zgromadzonym ten fakt pragnie uświadomić ich o doniosłości oraz reperkusjach moralnych ich wyroku.

Oskarżyciel, zwracając się do zebranego gremium, używa sformułowań bardzo subtelnych, mając na względzie fakt, że przemawia do ludzi z uprzywilejowanych klas społecznych, posiadających majątki i cieszących się powszechną estymą (prokurator jest zmuszony przyjąć taką taktykę, ponieważ Dymitr Karamazow był awanturnikiem, to cieszył się sympatią wśród lokalnej społeczności, szczególnie wśród kobiet). Kiryłowicz dostrzega konieczność zjednania sobie odbiorców, dlatego akcentuje obrzydliwość i niemoralność jego czynu, starając się wzbudzić w słuchaczach uczucie oburzenia i antypatii wobec oskarżonego. Przy odpowiednim nastawieniu emocjonalnym zgromadzonych, siła argumentów merytorycznych powinna zapewnić jemu zwycięstwo w starciu z obrońcą Karamazowa.

Choć skupiona przede wszystkim na funkcji informująco-pouczającej oraz zniewalającej, mowa prokuratorska nie jest pozbawiona elementów estetycznych. $\mathrm{Na}$ uwagę zasługują sekwencje przymiotnikowe, którymi posługuje się Kiryłowicz przy opisie członków rodziny Karamazow oraz odniesień do socjologii i filozofii. Przemowa prokuratora zawiera również odniesienia do literatury rosyjskiej, dzięki czemu uzyskuje barwny wydźwięk pod względem ekspresywnym. W ten sposób mowa Kiryłowicz jest nobilitowana stylistycznie.

Kompozycja mowy prokuratora jest transparentna i zachowuje klasyczny podział. Na wstępie Kiryłowicz zwraca się do osób, które są odpowiedzialne za rozstrzygnięcie całej kwestii i jednocześnie podkreśla znaczenie procesu. Następnie, prokurator nawiązuje do cynizmu społeczeństwa, które utraciło zdolność potępiania takich czynów, aby pod koniec wstępu zaakcentować konieczność rozbudzenia świadomości i solidarności społecznej. Rozwinięcie rozpoczyna się od opisu domu rodzinnego oskarżonego oraz historii jego ojca, Fiodora Karamazowa, który zostaje odmalowany jako niegodziwy rodziciel, „matacz” oraz „lizus”, który „,nagle przez niespodziewany ożenek dochrapał się kapitaliku" (TŹ). Następnie prokurator przywołuje postaci dwóch braci oskarżonego: Iwana oraz Aleksego, obydwu przedstawiając w złym świetle. Pierwszy zostaje ukazany jako psychicznie rozstrojony ateista a drugi zostaje sportretowany jako przebiegły dewot. Opisowi charakteru oraz okolicznościom, które doprowadziły do ojcobójstwa poświęca Kiryłowicz najwięcej czasu. Zakończeniem mowy jest przykład nierozsądku oskarżonego, który nie skorzystał z ,arcyrozsądnej rady” i nie zrezygnował z zamiaru ojcobójstwa, dając wyraz nie tylko swojej nieposkromionej żądzy mordu, lecz również głupoty.

Najbardziej interesującym składnikiem mowy prokuratora Kiryłowicza jest elokucja ${ }^{9}$. Kiryłowicz nie posługuje się językiem wyrafinowanym, a z drugiej strony

\footnotetext{
${ }^{9}$ Cf. Związki retoryki z dyskursem sądowym i szczególna rola elokucji są przedmiotem badań m.in. następujących autorów: Worsowicz, 2014; Tecław, 2015; Jabłońska-Bonca, Zeidler, 2016; Drabik, 2017.
} 
daleko mu do plebejskich sformułowań. Prokurator ma na względzie poziom intelektualny audytorium, dlatego jego mowa jest nade wszystko stosowna i pozbawiona przesadnych ornamentów; ponadto jego wywód charakteryzuje zaleta jasności stylu, która w tego rodzaju wystąpieniach jest istotnym elementem skutecznego przekonywania.

Poniżej przedstawione zostały wybrane figury i tropy, które znajdują naszym zdaniem zastosowanie w dydaktyce pod kątem rozwoju lingwistycznych zasobów komunikacyjnych w wystąpieniach publicznych.

(1) Accumulatio (nagromadzenie) to figura retoryczna, która polega na użyciu wielu semantycznie lub składniowo analogicznych określeń. Przykład: „Zmęczony, wyśmiany, głodny, sprzedawszy zegarek, aby mieć na podróż [...], udręczony zazdrością o zostawiony w mieście obiekt swej miłości [...]” (TŹ). Ta figura posłużyła oskarżycielowi do wzmocnienia wypowiedzi poprzez uwypuklenie stanu fizycznego i emocjonalnego w jakim oskarżony się znajdował, jego nędzy i desperacji.

(2) Anadiploza, czyli figura, która polega na rozpoczynaniu zdania lub członu zdania od wyrazu znajdującego się na końcu poprzedniego zdania lub członu (Korolko, 1990: 108). Przykład: „Ale trzeba mu pieniędzy, pieniędzy przede wszystkim..." (TŹ). W tym przypadku prokurator wskazuje motor działań oskarżonego, jego chęć zysku, materializm, pazerność.

(3) Anafora, która służy semantycznemu uwypukleniu myśli. To figura, która polega na celowym powtarzaniu tego samego słowa lub zwrotu na początku zdań lub członów (Korolko, 1990: 108). Przykład: „nie wierzcie mi, nie wierzcie, ja będę mówił, a wy mi nie wierzcie" (TŹ). W przytaczanym fragmencie prokurator Kiryłowicz wciąga publiczność w grę, pozornie przestrzegając słuchaczy przed swoją (nie)wiarygodnością, pragnąc zwrócić uwagę na okrucieństwo i bezduszność oskarżonego.

(4) Eksklamacja (wykrzyknienie), które służy podkreśleniu właściwej części wypowiedzi, może wyrażać afektowane zdziwienie lub zachwyt. Przykłady: „O, nie chcę wysnuwać z tego konkluzj”; „O, on jest otwarty i szczery” (TŹ).

(5) Etopoia to figura myśli, która polega na wypowiadaniu myśli innej osoby (Korolko, 1990: 118), w poniższym przykładzie to prokurator wypowiada myśli oskarżonego: „Widzisz przehulałem połowę twoich pieniędzy i dowiodłem, że jestem słabym i niemoralnym człowiekiem [...]" (TŹ). To silnie oddziałująca figura pełniąca istotną funkcję w perswazji. Oskarżyciel werbalizując domniemane myśli oskarżonego zamierza uwiarygodnić swoją mowę.

(6) Metafora polega na zestawianiu $\mathrm{z}$ sobą obcych znaczeniowo wyrazów w taki sposób, że jeden z nich zyskuje nowe znaczenie. Przykład: „Zdaje się, że w nim jednak nieświadomie i tak wcześnie znalazła wyraz ta nieśmiała desperacja, z jaką wielu członków naszego społeczeństwa, zląkłszy 
się cynizmu i jego wyuzdania, a mylnie kładąc je na karb europejskiej cywilizacji, dopada, jak sami mówią, <ziemi ojczystej>, rzucają się, że tak powiem, w macierzyńskie objęcia ziemi rodzinnej, jak dzieci przerażone przywidzeniem, i u wyschniętej piersi znużonej macierzy pragną bodaj tylko zasnąć spokojnie i nawet przespać całe życie, byleby nie widzieć przerażających potworności" (TŹ). Przytaczana tu metafora odnosi się do brata oskarżonego, Aleksego, który zdaniem prokuratora ulega europejskim modom; $\mathrm{z}$ jednej strony jest on jednym $\mathrm{z}$ wielu ludzi, którzy ulegają zachodnim trendom, $\mathrm{z}$ drugiej zaś strony prokurator sugeruje, iż jest on na tyle słaby intelektualnie, że nie potrafi wybrać między narodowymi wartościami a wartościami europejskimi. Oskarżyciel uważa ponadto, że głęboka pobożność Aleksego jest ostentacyjna i wymuszona, a ten pragnie uzyskać jedynie aprobatę społeczeństwa wobec swojej postawy i wzbudzić sympatię do swojej osoby.

(7) Pytanie retoryczne, które służy wywołaniu zadumy, wzbudzeniu refleksji lub pozwala przybliżyć słuchaczowi temat, który zostanie następnie szczegółowo omówiony. Przykład: „Gdzie tkwią przyczyny naszej obojętności, naszego nieomal obojętnego stosunku do takich spraw, do takich objawów epoki, zwiastujących nam niezbyt godną pozazdroszczenia przyszłość?” (TŹ). Tak sformułowane pytanie nie wymaga naturalnie odpowiedzi, a jedynie skłania do rozmyślań nad stanem społeczeństwa, przedstawia punkt widzenia komunikatora oraz pozwala zyskać milczącą aprobatę publiczności.

Poza przytoczonymi i omówionymi powyżej przykładami, w mowie oskarżycielskiej Kiryłowicza znajdują się jeszcze dwa retoryczne chwyty.

(8) Odniesienia literackie

Przywołanie postaci z „Martwych dusz” Gogola stanowi nawiązanie do literatury i świadczy o tym, że mówca pokłada wiarę w pewien potencjał intelektualny odbiorców, którzy to nawiązanie muszą zrozumieć. Poza tym Kiryłow implikuje, że literackie postaci nie dorównują cynizmem i podłością ludziom takim jak oskarżony Dymitr Karamazow. Przykład: „Gdyby bowiem do jego trójki wprzęgnąć tylko jego własnych bohaterów, Sobakiewiczów, Nozdriewów i Cziczikowów, to choćby miał najlepszego forysia, niedaleko by zajechał!" (TŹ 8).

(9) Cytaty

„Après moi le déluge” (Po mnie choćby potop) to nawiązanie do maksymy pochodzącej z języka francuskiego, której autorstwo przypisywane jest kochance króla Ludwika XV, Madame de Pompadour. Kiryłowicz używa tej sentencji chcąc obnażyć nihilizm oskarżonego, jego przewrotną i wichrzycielską naturę. Innym przykładem zastosowania cytatu jest przytaczanie wypowiedzi świadków w procesie. Kiryłowicz przytacza za Rakitinem, jednym ze świadków: „Odczuwanie głębi upadku jest równie niezbędne tym 
rozkiełznanym, niepowściągliwym naturom jak i odczuwanie wzniosłej szlachetności” (TŹ). Oskarżyciel stosuje jeden z najpopularniejszych krasomówczych wybiegów: przytacza informację bez kontekstu, dostosowując ją do swojego perswazyjnego celu, tutaj po raz kolejny Kiryłowicz zwraca uwagę na pełen wrogości i żądz charakter oskarżonego.

Mowa Kiryłowicza stanowi jedynie preludium do właściwej części wypowiedzi opisu momentu zbrodni. Celem wstępu było zbudowanie odpowiedniego napięcia, a przybliżenie słuchaczom proweniencji oskarżonego i jego rodziny pomogło prokuratorowi określić okoliczności ojcobójstwa.

Należy również wspomnieć o postawie samego prokuratora. $Z$ uwag narratora (który jest jednym ze świadków procesu) można wywnioskować, że jego mowa była wyzwaniem szczególnie wymagającym emocjonalnie. Prokurator „zaczął swoją mowę oskarżycielską, trzęsąc się po prostu w nerwowym dreszczu, z zimnym, chorobliwym potem na czole i skroniach, czując na przemian ziąb i żar w całym ciele" (TŹ). Kiryłowicz miał świadomość, że sprawa Karamazowa może stać się szczytowym osiągnięciem jego adwokackiej kariery. Ponadto jego zaangażowanie wykraczało poza zwykłe ramy zawodowego obowiązku. Dymitr Karamazow poniżył Kiryłowicza w jednej z wcześniejszych, publicznych dysput, dlatego prokurator mimo autentycznej chęci ocalenia „ocalenia społeczeństwa” zamierzał także „zadośćuczynić" swojemu rywalowi.

Mowa Kiryłowa jest doskonałym przykładem materiału treningowego dla kursów akademickich w obszarze prezentowania publicznego. Może posłużyć analizie użytych środków perswazji (retorycznych), a także stanowić inspirację dla mówców podczas ćwiczeń. Autorom niniejszego studium przyświeca założenie, że o ileż bardziej atrakcyjne w sferze lingwalnej, może nawet bałamutne i filuteryjne, stałyby się prezentacje studentów, gdyby wyposażyć ich w cały ten repertuar figur i tropów retorycznych.

\section{Uwagi końcowe}

Najważniejszym wnioskiem płynącym z niniejszego studium, mającego charakter analityczno-przeglądowy, jest dostrzeżenie zapotrzebowania rynku pracy na kształcenie kompetencji miękkich, w tym nade wszystko na kształcenie kompetencji komunikacyjnych: interpersonalnych i retorycznych. Autorzy dokumentu „Analiza kwalifikacji i kompetencji kluczowych dla zwiększenia szans absolwentów na rynku pracy" ${ }^{10}$ odnotowują:

Luka w zakresie kompetencji interpersonalnych sugeruje, że dla tego obszaru posługiwanie się językiem ojczystym powinno być przede wszystkim postrzegane w kontekście

\footnotetext{
${ }^{10}$ Op. cit. s. 88.
} 
wystąpień publicznych. Oznacza to kształcenie umiejętności retorycznych studentów w różnych okolicznościach, różnymi metodami, zarówno w ramach zajęć, jak i poprzez zachęcanie do aktywnego udziału w konferencjach, organizację debat, itp. W przypadku nauk społecznych sytuacja wygląda bardzo podobnie jak w przypadku absolwentów nauk humanistycznych - pracodawcy oczekują w pierwszej kolejności kompetencji związanych z komunikacją oraz sprawnego przetwarzania informacji, ponadto wysokiej samoorganizacji $[\ldots]$.

Wychodząc naprzeciw zapotrzebowaniom rynku pracy uniwersytety, niezależnie od profilu kształcenia (mamy tu na myśli nade wszystko uczelnie techniczne i medyczne), powinny zadbać o uzupełnienie programów kształcenia o treningi interpersonalne oraz sztukę wystąpień publicznych. Należałoby pójść za oczekiwaniami pracodawców wyrażanymi explicite w cytowanych powyżej badaniach i analizach potrzeb i stworzyć absolwentom warunki do proaktywnego rozwoju umiejętności interpersonalnych i retorycznych, które zawierają się w szerszym pojęciu kompetencji komunikacyjnych. Za Hipolitem Kiryłowem można by zaś powtórzyć: „Gdzie tkwią przyczyny naszej obojętności, naszego nieomal obojętnego stosunku do takich spraw, do takich objawów epoki, zwiastujących nam niezbyt godną pozazdroszczenia przyszłość?" (op. cit.).

\section{Bibliografia}

Allhoff, D.W. i W. Allhoff. 2008. Sztuka przekonywania do własnych racji. Kraków: Wydawnictwo WAM.

Argyle, M. i M. Henderson. 2005. Körpersprache und Kommunikation. Paderborn: Junfermann.

Barłowska, M., Budzyńska-Daca, A. i P. Wilczek, (red.). 2008. Retoryka. Warszawa: Wydawnictwo Naukowe PWN.

Becker, G.S. 1964. Human capital. A theoretical and empirical analysis, with special reference to education. Chicago: University of Chicago Press.

Bhattacharyya, E. 2018. "Stakeholders perspective on communicative competence in Industry 4.0: Walk the talk of informative technologists". SHS Web of Conferences 53. 2-12.

Bielak, M.I., Puppel, S. i W. Maliszewski, (red.). 2018. Linguolabourese: language and communication in action. Advances in elinguistics. Piła: Wydawnictwo PWSZ.

Budzyńska-Daca, A. 2008. „Sztuka argumentacji”. W zbiorze: Barłowska, M., Budzyńska-Daca, A. i P. Wilczek, (red.). 2008. Retoryka. Warszawa: Wydawnictwo Naukowe PWN. 57-76.

Dobek-Ostrowska, B. 2006. Komunikowanie polityczne i publiczne. Warszawa: Wydawnictwo Naukowe PWN.

Dostojewski, F. 1913. Bracia Karamazow. Warszawa: Biblioteka Dzieł Wybranych.

Drabik, B. 2007. „Retoryczne "elocutio" i wybrane zagadnienia teorii komunikacji a problem jasności i stosowności języka prawniczego". W zbiorze: Sobczak, B. (red.). Powinowactwa retoryki. Poznań: Wydawnictwo Naukowe UAM. 107-120.

Gis, A. i M. Wobalis. (red.). 2016. Polonista na rynku pracy. Poznań: Wydawnictwo Naukowe UAM.

Gondek, P. 2015. "Communio and communicatio: the role of communication for participating in public life". W zbiorze: Tarasiewicz, F.P. (red.). Studia Gilsoniana 4:1. Cromwell: The International Etienne Gilson Society. 17-28. 
Jabłońska-Bonca, J. i K. Zeidler. 2016. Prawnik a sztuka retoryki i negocjacji. Warszawa: Wolters Kluwer.

Kohout, J. 2006. Retoryka. Mowa zjednuje ludzi. Gliwice: Wydawnictwo Helion.

Korolko, M. 1990. Sztuka retoryki. Przewodnik encyklopedyczny. Warszawa: Wiedza Powszechna.

Krawczak, M. 2017. „Poznańska szkoła ekolingwistyki”. Scripta Neophilologica Posnaniensia XVII. 145-192.

Kulczycki, E. 2012. Teoretyzowanie komunikacji. Poznań: Wydawnictwo Naukowe Instytutu Filozofii UAM.

Latoch-Zielińska, M. 2016. „Polonista to nie tylko nauczyciel”. W zbiorze: Gis, A. i M. Wobalis. (red.). 2016. Polonista na rynku pracy. Poznań: Wydawnictwo Naukowe UAM. 25-39.

Maes, J.D., Weldy, T.G. i M.L. Icenogle. 1997. "A managerial perspective: oral communication competency is most important for business students in the workplace". Journal of Business Communication 34(1). 67-80.

McNatt, D.B. 2019. "Enhancing public speaking confidence, skills, and performance: An experiment of service-learning". The International Journal of Management Education 17. 276-285.

Michałowski, D. 2015, „Ambiwalencja i tajemnica. Wokół antropologii filozoficznej Dostojewskiego”. Logos i Ethos 38.1. 7-24.

Morreale, S.P., Spitzberg, B.H. i J.K. Barge. 2007. Komunikacja między ludźmi. Warszawa: Wydawnictwo Naukowe PWN.

Ngang T.K., Chan T. i U.D. Vetriveilmanyc. 2015. "Critical issues of soft skills development in teaching professional training: educators' perspectives”. Procedia: Social and Behavioral Sciences 205. 128-133.

Norwood, F.B. i S.R. Henneberry. 2006. "Show me the money! The value of college graduate attributes as expressed by employers and perceived by students". American Journal of Agricultural Economics 88.2. 484-498.

Puppel, S. i J. Puppel. 2008. „Gestosfera jako istotny składnik przestrzeni publicznej: wstępny zarys problematyki”. Oikeios Logos 4. 1-8.

Puppel, S. 2008. "Communicology: remarks on the reemergence of a paradigm in communication studies". W zbiorze: Puppel, S. i M. Bogusławska-Tafelska. (red.). New pathways in linguistics. Olsztyn: Uniwersytet Warmińsko-Mazurski. 11-22.

Puppel, S. i M. Bogusławska-Tafelska. (red.). 2008. New pathways in linguistics. Olsztyn: Uniwersytet Warmińsko-Mazurski.

Puppel, S. 2007. „Interlingwalizm czy translingwalizm? Interkomunikacja czy transkomunikacja? Uwagi w kontekście współistnienia języków naturalnych w ramach globalnej wspólnoty kulturowo-językowo-komunikacyjnej”. W zbiorze: Puppel, S (red.). Społeczeństwo-kultura-język. W stronę interakcyjnej architektury komunikacji. Poznań: KEKO UAM. 79-94.

Puppel, S. 2004. "An outline of a domain-resource-agent-access-managment (DRAAM) model of human communication: towards an ecology of human communication". Electronic Journal Oikeios Logos 1. 1-26.

Suleman, F. 2018. „The employability skills of higher education graduates: insights into conceptual frameworks and methodological options". Higher Education 76.2. 263-278.

Tarasiewicz, F.P. (red.). 2015. Studia Gilsoniana 4.1. Cromwell: The International Etienne Gilson Society.

Tecław, B. 2015. „Retoryka pytań w dyskursie sądowym”. Res Rhetorica 3. 2-15.

Teichler, U. 2009. Higher education and the world of work. Conceptual frameworks, comparative perspectives, empirical findings. Rotterdam: Sense Publishers.

Urbaniak, A. 2018. „Piękny umysł. O konieczności rozwijania kompetencji interpersonalnych u studentów uczelni technicznych”. W zbiorze: Bielak, M.I., Puppel, S. i W. Maliszewski, (red.). Linguola- 
bourese: language and communication in action. Advances in elinguistics. Piła: Wydawnictwo PWSZ.

Urbaniak, A. 2014. Rola elementów werbalnych i niewerbalnych $w$ komunikacji politycznej końca XX i początku XXI wieku na podstawie analizy wybranych wystapień medialnych polskich polityków. Poznań: Katedra Ekokomunikacji UAM.

Velasco, M.S. 2012. "More than just good grades: candidates' perceptions about the skills and attributes employers seek in new graduates". Journal of Business Economics and Management 13(3). 499-517.

Wiertlewska, J. 2017. "Is it possible for doctors to treat their patients and communicate with them as if they were their partners?" W zbiorze: Wiertlewska, J. (ed.). Komunikacja. Dydaktyka języka obcego w szkole wyższej. Toruń/Bydgoszcz: Dział Wydawnictw Collegium Medicum w Bydgoszczy, Uniwersytet Mikołaja Kopernika w Toruniu.

Wiertlewska, J. (ed.). 2017. Komunikacja. Dydaktyka języka obcego w szkole wyższej. Torún/Bydgoszcz: Dział Wydawnictw Collegium Medicum w Bydgoszczy, Uniwersytet Mikołaja Kopernika w Toruniu.

Wobalis, M. 2016. „Polonista a rynek pracy”. W zbiorze: Gis, A. i M. Wobalis. (red.). Polonista na rynku pracy. Poznań: Wydawnictwo Naukowe UAM. 11-24.

Worsowicz, M. 2013. O „duchu stosowności”: teoria retoryczna a wspótczesna praktyka medialna. Łódź: Wydawnictwo Uniwersytetu Łódzkiego.

Zgółka, T. 2017. „Retoryka a kultura języka”. Poradnik Językowy 2. 41-50.

\section{Źródla internetowe}

IS 1: www.rp.pl/artykul/1089269-Kudrycka--Humanisci-musza-wyjsc-ze-skansenu.html\#ap-1 [dostęp: 20.09.2019].

IS 2: https://targetjobs.co.uk/careers-advice/career-planning/273051-the-top-10-skills-thatll-get-you-a-jobwhen-you-graduate [dostęp: 20.09.2019].

IS 3: https://www.thebalancecareers.com/top-soft-skills-employers-seek-1986632 [dostęp: 20.09. 2019]. 